\title{
The role of the plot in engendering environmental quality: From unplanned favelas to the planned subdivisions of new blocks
}

\author{
Maria Cristina Villefort Teixeira, Marieta Cardoso Maciel, Staël \\ Alvarenga Pereira Costa \\ Escola de Arquitetura. Universidade Federal de Minas Gerais. \\ Belo Horizonte, Minas Gerais, Brazil \\ E-mail: mcrisvt@gmail.com; marietamaciel@gmail.com; staelalvarenga@gmail.com
}

\begin{abstract}
This work discusses the importance of the site in the morphological structuring of urban centres. Studies on the implantation of the city of Belo Horizonte, located in the state of Minas Gerais, show that the occupation of the city occurred initially in the valleys. This was due to the favourable conditions of the topography, which allowed an orthogonal layout in the central area. In spite of this, since the city's foundation, the most rugged areas have been occupied by favelas, whose layout differed from the dominant pattern. As flat areas became scarce, the hilly regions, possessing long strips of land, were also subdivided and exploited due to their substantially lower land prices. Although the favelas sprung up spontaneously and the new settlements were planned, both had similarities in the layout of the streets which were adjusted to the steep contours and the geological conditions of the terrain. At the same time, the plot defined another configuration in the subdivisions, in which the building was occupied by only a single family and, in most cases, the building was separated from the street by high walls. As a consequence, the relationship between public and private space became severely compromised. In the case of the favelas, the formal inexistence of the plot is demonstrated in the juxtaposition of the dwellings, in which each residence is constructed above another in extremely confined space. The relationship with the street also differs in these places, since the 1st floor often freely connects to the street, integrating the dwelling with the public space and thus contributing to the social life of the community. This is furthermore in contrast to the previously noted walled environments characterising planned areas. The analysis of these parameters could profitably be utilised in new designs that appropriate some of the popular solutions better suited to the environment, and in turn, integrate them into public policy.
\end{abstract}

Keywords: Belo Horizonte, site, settlements, urban growth, urban fabrics

\section{Introduction}

Morphologists contend that the urban form is a product of historical periods representing, and influenced by, political, economic and social facts that transform and modify the form's configurations which, in turn, contribute to defining specific morphological periods. It is also widely thought that such periods often amalgamate on the site, forming layers, many of which become lost or poorly identified. These periods, however, can be recognized as a successive continuum of urban fabric that obeys urban patterns and norms which have materialized over time. The identification and study of urban fabric, resulting from social and economic inequalities, is relatively rare because the urban form in traditional studies 
has become established and the urban fabric has been reduced to smaller variables.

Thus, developing countries can be the subject of innovative research in which the work carried out can help to assess the relevance of applying the concepts of urban morphology to situations that are not well explored. Such sources and examples can be found and observed in Brazilian cities. On the one hand they exhibit, formal and planned spaces, manifesting regular urban fabric, containing single or multifamily dwellings, inserted into well-defined plots and blocks, well served by infrastructure. On the other hand, however, they are replete with the unregulated spaces, located in areas of risk that form dense urban fabric, with reduced plots and badly delineated blocks which form continuous patches on the landscape.

Although the phenomenon is present in several Brazilian cities, this work presents and discusses its appearance in those planned in the nineteenth century and suggests that planning, for the most part, has been aimed at areas accommodating the economically better attended social classes. However, significantly and in spite of this, it is possible to observe that the urbanization resulting from the collective and spontaneous decision making of the favela manifests similarities to the planned areas and that the former could even bring innovative social qualities to those areas destined for high income social classes.

In order to research such tendencies and phenomenon, the Brazilian city of Belo Horizonte was duly chosen as a case study. Designed to be the capital of the state of Minas Gerais at the end of the 19th century, the planned metropolis was expected to grow within pre-established and projected limits of 200 thousand inhabitants (Barreto 1996). The city has however spread with little planning, expanding at an extremely rapid pace as a result of both private/individual decision-making and political input. Consolidation, since foundation in the $1890 \mathrm{~s}$, has produced multifaceted space, presenting fabric planned for different urban areas and destinations. It has also included a designated marginal space for workers who built the city, marginalized by the planners.
More specifically, this paper has analysed the process of land subdivisions in Belo Horizonte and the forms of building settlement on existing plots, thus facilitating an evaluation of their impact on the urban landscape. As such, the morphological concepts from the traditional schools of M.R.G Conzen (2004) and Caniggia e Maffei (2001) were applied. In addition, observations on favelas and spontaneous appropriations were based on the classic studies carried out by Brazilian researchers, such as Maricato (1982, 2015), Rolnik (2015) and Bonduki (1999). Also referenced were studies that were remarkable for their formal aspect and implications in relation to the landscape, such as Santos (2008), who contributed to revealing the social aspects inherent in urban occupation, Pereira Costa (2004), Perna (2012), Gimmler Netto (2014), as well as, research undertaken by the Landscape Laboratory. Such references have thus contributed significantly to this text and allowed reflection on the forms of urban fabric and their environmental and social quality.

\section{The urban form of Belo Horizonte and its development}

As previously mentioned, the main characteristics of Belo Horizonte have emerged through zoning and land subdivision. With a population that has grown to around 2.3 million inhabitants (IBGE 2011), the city was implanted across two geomorphological domains consisting of gneissic-migmatitic rocks and specific sedimentary sequences manifesting lithological diversity. At the junction of the two domains, there is a depression that divides the sub-basins, along which the river (Ribeirão Arrudas) runs, dividing the city between east and west. Several smaller tributaries are connected to this watercourse, which acts as the main hydrological system of the settlement (Ferreira, 1997).

The urban plan of the new capital was subdivided into three large zones: the rural, the suburban and the urban zone and conceived in an orthogonal pattern. The zones were designed to serve different purposes in a total urbanized 


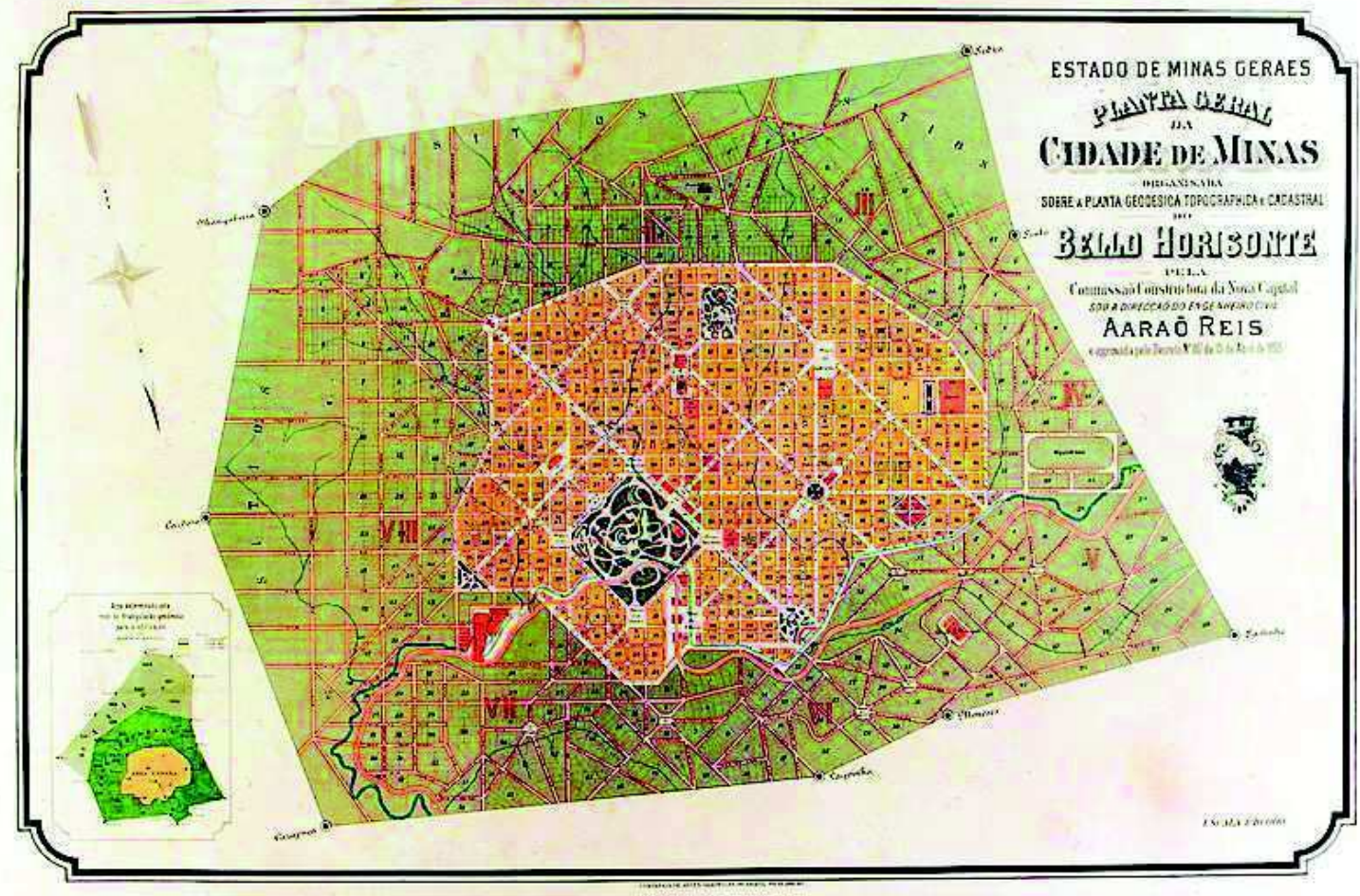

Figure 1.

The rural, the suburban and the urban zone of Belo Horizonte

area of 1200 hectares. The general planning of the new city was based on the positivist philosophy popular in that era. As such, and in relation to Urbanism, this stressed the use of metrics, rectification and geometric figures, resulting in a design of urban forms settled on an ortogonal grid. (PLAMBEL, 1986). Technology was considered to offer feasible answers to physical constraints. In order to address these issues, the technocratic leaders of the new capital undertook projects, such as the channelling of streams and the grounding of natural depressions for the construction of plazas and a monumental axis (Pereira Costa, 2004).

However, the development of the city was not uniform as it was prone to wide administrative and management differences and ideology. This resulted in an attempt to control the capital with a poorly structured administrative and technical state that met the formal requirements of controlling expansion and the demands of construction, in compliance with developers. The solution found was to govern with developers, with the resulting definition of the area of intervention - the suburban area. As there were no defined rules and structured urban parameters, everything was subsequently defined by entrepreneurs.

Thus, the original project of wide roads and regular plots, designed in the urban area, was adapted to the suburban area. The construction of a railroad branch in a westerly direction, parallel to the river, induced new occupation. This was reinforced by the construction of transhipment stations along the railway axis, the vector of which led to the emergence of small nuclei that gradually consolidated themselves as districts destined for the residence of the working population, distant from the original urban area. (PLAMBEL, 1986). The streets had their width reduced and parcels dismembered, whilst requirements for the development of green and institutional areas were put on hold and would only be resumed in the 1940s, when much of the urban quality had already been compromised (Landscape Laboratory, 2010).

Subsequently, the expansion of the city, in its specificity, has also revealed the most recent process of urban land appropriation in Brazilian 


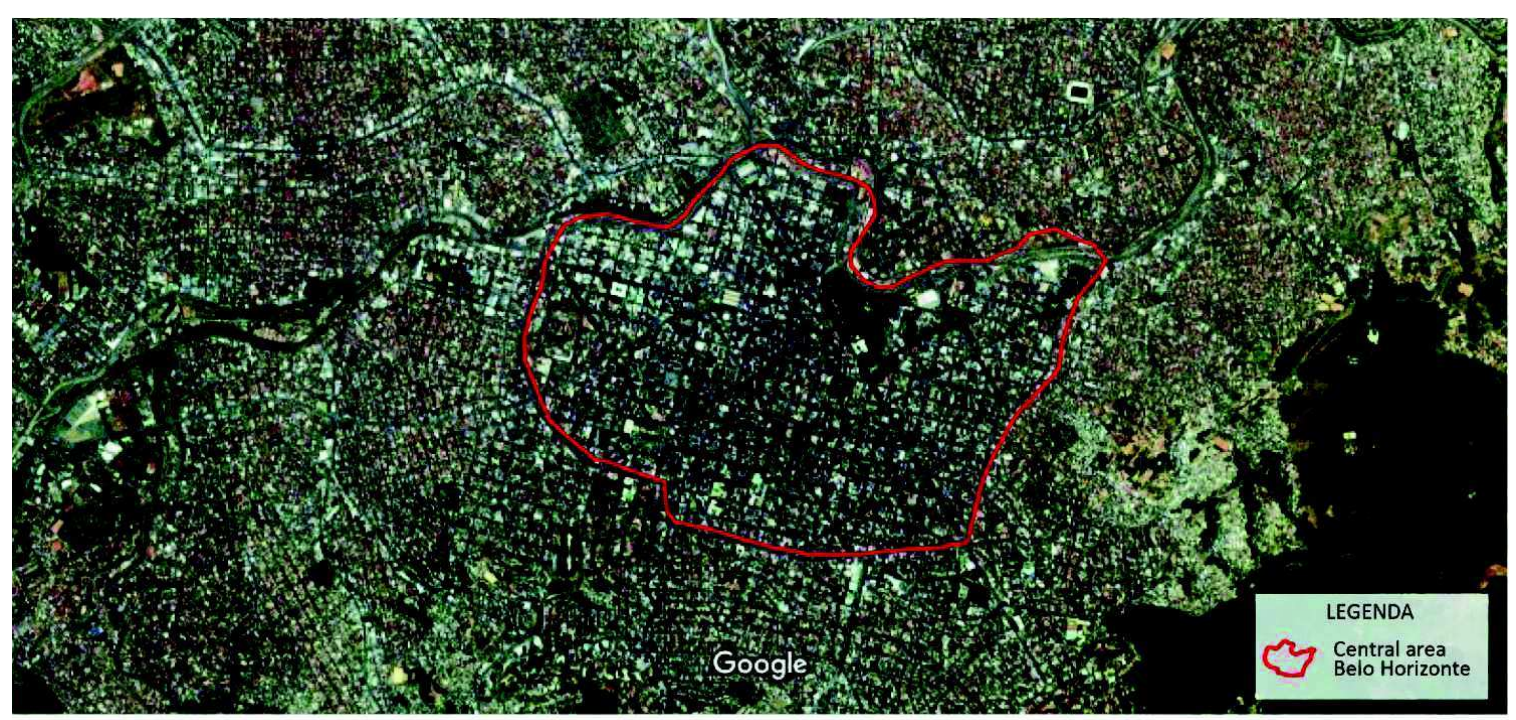

Figure 2.

Different urban fabrics in Belo Horizonte

cities: the occupation of the metropolitan borders. In these areas of expansion, diversified types of occupation are characterized by heterogeneity and segregation, such as industry, low-income occupation and closed condominiums, the latter destined for singlefamily, high-income housing (Macedo, 1999).

This process reveals the logic of the metropolitan real estate market which encapsulates changes in lifestyle and consumption and the discourse of an escape from the city and its accompanying violence, together with the search for an idealised contact with nature.

Such duality, printed on the patterns of urban fabric, reveals how the state deals with the management and provision of public services. The formal urban fabric receives a wide range of facilities, in contrast to the informal sector which remains scarcely provided for.

\section{The urban form}

The urban zone was structured so that activities were implemented with a view to accommodating the administrative and residential function of the civil servants who worked there, the area being circumvented by an inner ring road (Barreto1996). The main central area is then located within this road known as Avenida do Contorno. This same region acts as the main centre of the metropolitan core and is currently classified as the hypercentre of the capital. Two other centres have played the role of commercial and commercial sub-centres both of which act as cores for local retail business. (Pereira Costa et al, 2010).

The roads leading to the two sub-centres characterize the two main highways installed along the waterways, one that flows west and the other to the north (Secretaria Municipal de Coordenação de Política Urbana e Ambiental, 2002). The west and north axis comprise the most significant growth expansion vectors and represent areas where industries are concentrated beyond the industrial city and have spread along the main axes connecting Belo Horizonte to São Paulo and Brasília. The northern vector has also witnessed expansion boosted by the settlement of cement extraction industries which in turn have required road networks and transportation facilities.

Two other smaller axes lead to these expansions: one extends to the south and east, while the other, to a lesser extent, appears in the northwest and northeast and comprises favelas and other outlying areas of the city. Another axis consists of a highway that expands to the south (Belo Horizonte-Rio de Janeiro) whose borders house high-class single-family houses.

In summary, the city, as presented by its 2017 structure, manifests a layout in stark contrast to 
the original publicly planned metropolis, being contemporaneously controlled by the private sector.

\section{The Belo Horizonte type - morphological process in 2017}

The morphological process resulting from political, economic and social pressures has taken the form of four urban types of fabric, which, in turn, have unfolded into several other types. The objective in this paper is to discuss the two types of models of urban expansion and to compare them, as well as those types resulting from the foundation and expansion of the city.

\section{The original type}

The first type originated from the formation of the city and was implanted in an urban plan consisting of 120 -meter-long blocks, subdivided into 10 plots each with a frontage of 12 meters and accommodated in 12-meterwide streets. Models of six differentiated houses were built according to the functional hierarchy of the civil servants who came from Ouro Preto (the state's former capital) to live in Belo Horizonte. The basic type was built on two floors, aligned to the street and remained unchanged until the 1940s, when changes in urban legislation occurred.

From this period, and as a result of the legislation, new types emerged, mainly for commercial uses, allowing greater occupation density and three-story high multifamily use. A growing number of additions at the rear of the plots led to the appearance of outhouses which could be rented and amounted to $40 \%$ of all irregular constructions. (Plambel, 1986).

These findings led to the formulation of new models, implanted in a Land Use and Occupancy Law, which combined, in a mathematical model, the occupancy index of the lot $\mathrm{x}$ type of use allowed. According to Plambel, the old pattern did not take into account the functions, variety and diversity of urban life, thus it proposed a combination of occupation and land subdivision for a given zoning (Pereira Costa, 2004).

The planning laws of 1976 and 1985 led to modifications in the use of buildings, typologies, in their volumes and in the increase in high rise developments in the urban and suburban zones. This period was characterized by the emergence of larger, high rise buildings, adjoining of the plots and densification of the urban landscape. The landscape was thus transformed and the relationship between public and private space was lost due to the construction of walls and the presence of commerce on the first floor of such developments. Growing urban violence has subsequently led to the elevation of walls, often of transparent glass panels that allow the visual permeability of the residents with the public space, whilst access to private units only occurs via control mechanisms, watchtowers and video cameras.

These aspects can be observed throughout the city, comprising the urban and suburban areas. In the formerly rural areas, residential types of one to two storeys are the main forms that reproduce the occupancy standards of the 1940 decree, but the ratio of public and private space is similar to that observed in the old urban and suburban areas. The great majority of the territory is structured by this urban fabric. There are, however, two other phenomena that stand out. One of them appears at the foundation of the city: the spontaneous occupations destined for the low income population. The other is the result of the demands of the upper middle class, which has sought privacy and security in more distant places. In both cases the conditions have materialized on similar sites and deployments, but with differences in type of deployment batches and in infrastructure and construction standards.

\section{The urban fabric of the spontaneous settlements}

Favelas emerged in the vacant areas near to amenities under construction and dictated by the socioeconomic conditions of their residents and precarious planning patterns that, did not take into account, the need to shelter the 


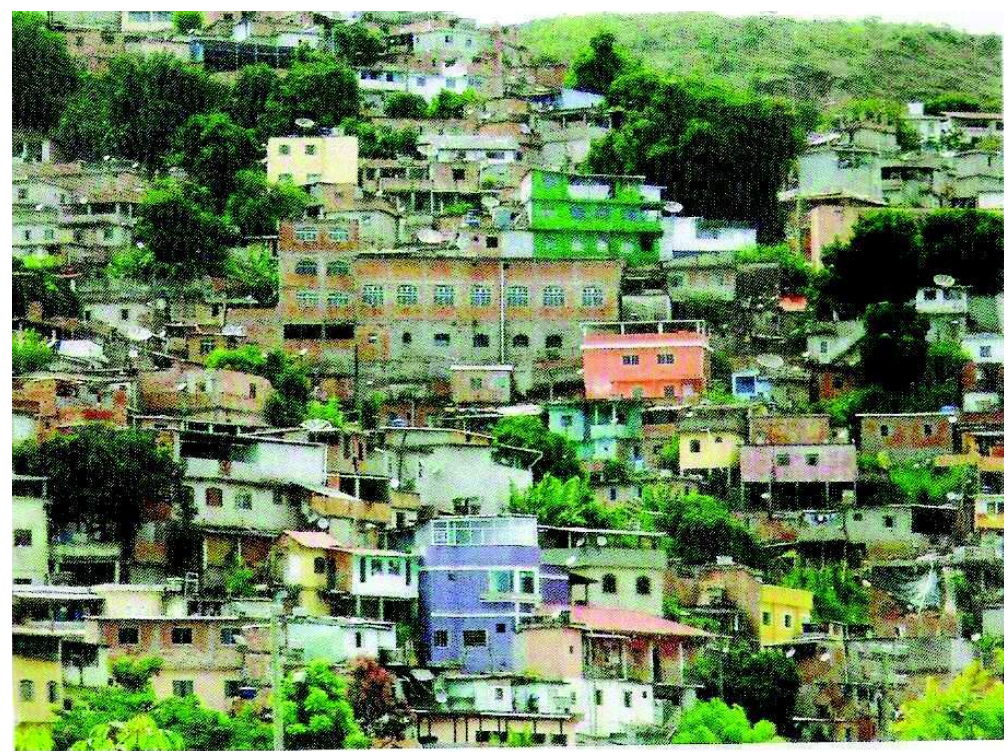

Figure 3.

Spontaneous occupation area

workforce, indispensable for the implantation of the new capital, in the construction of public buildings and road infrastructure (Libânio et al, 1986). Moreover, because of the tolerance of the authorities, coupled with the need of the inhabitants to be close to their workplace, settlements have expanded as the city has grown and consolidated itself as urban fabric within spontaneous occupation areas.

This fabric, located on slopes, is the result of a type of occupation that occurs by means of an axis which joins the road from the official road system and leads to the top of the hill, the main street being installed on the ridge (Caniggia and Maffei, 2001). It also divides the settlement into two slopes whose subdivision forms streets parallel to the ridge, follow the contour of the contour lines and form long blocks. The layout of the street has consequences for pedestrians, as the blocks force them to travel long distances before reaching a street or their houses. To minimize this inconvenience, people tend to take shortcuts through the properties of others, thus creating a system of uneven paths. Moreover, due to the formation of the terrain, to the topography and to the steep slopes, these paths can exacerbate the risk of landslides.

\section{The plot pattern}

Most of the plots are aligned with the streets parallel to the ridge. As the street follows the contours of the site, these plots are located above or below the street. In areas with geo-morphological characteristics not recommended for housing occupancy, there may be damage, as residents tend to cut into the land to build their houses on a single level. This leads to soil instability and brings risks of landslides and flooding due to poor drainage. (Pereira Costa et al, 2010). At the beginning of the occupation, the houses are predominantly single floor dwellings, with few houses having second floor additions.

\section{The basic type}

The typical house, acknowledged by Caniggia and Maffei (2001) as the basic type, is about $30 \mathrm{~m}^{2}$ and consists of two bedrooms, a small kitchen and a bathroom, all covered with asbestos tiles. Plots are reduced, presenting an average area of $70 \mathrm{~m}^{2}$. The construction of the dwellings takes place in the middle of the plot, in alignment, with small areas/corridors, at the rear and side of the dwelling, located close to the limits.

During the first phase of the house, a narrow area of about $1.00 \mathrm{~m}$, on average, is left along one of the sides of the plot and is occupied at later stages of the expansion. The implementation of plots on slopes does not 


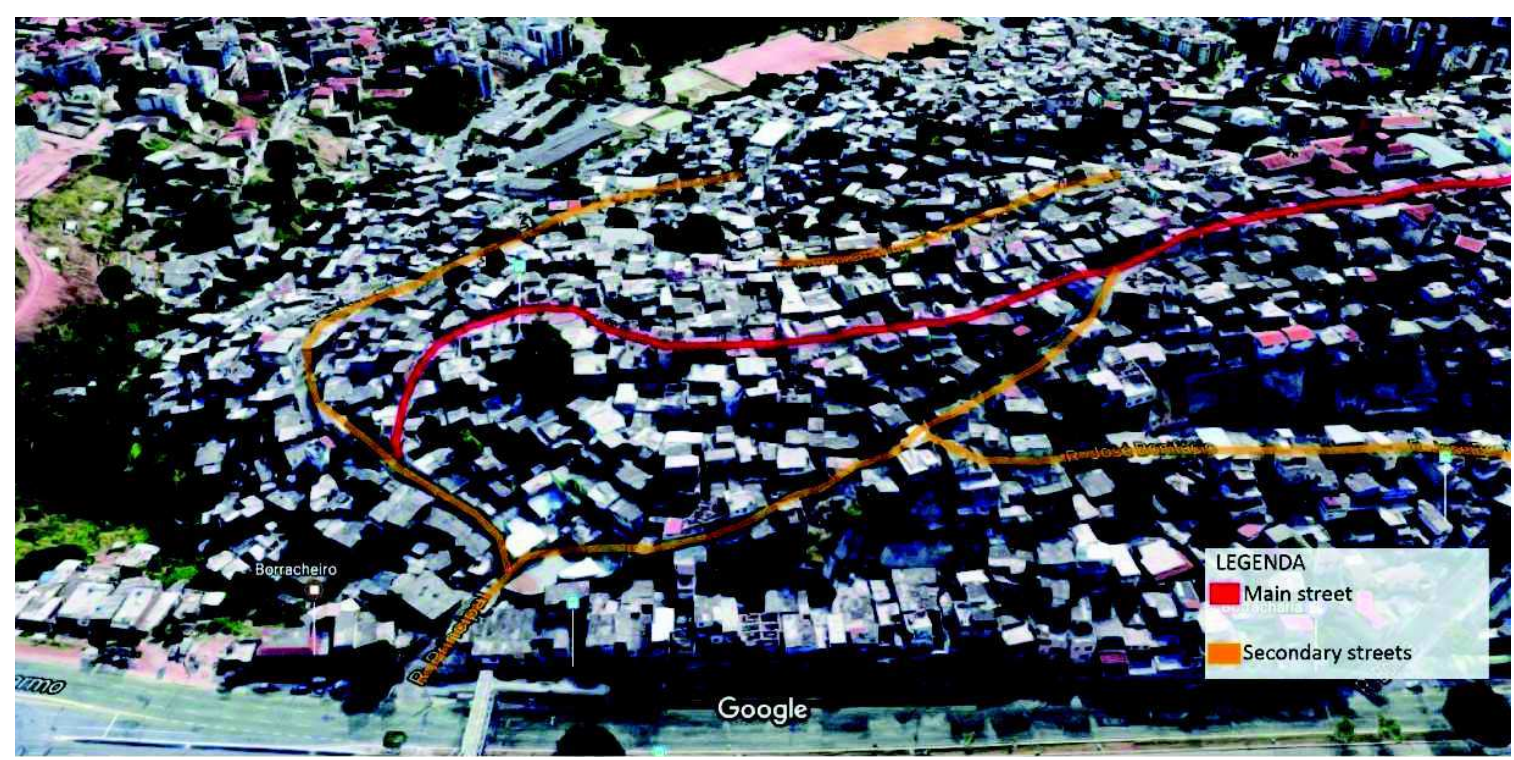

Figure 4.

Main street on the top of the hill

favour the use of the confined internal space for leisure activities or domestic services. As a result, many of these activities take place on the street and the street becomes an extension of the house. When the occupants feel secure and realize that they will not be evicted, they invest time and the little money they have to build better homes and new additions and decks are duly added.

\section{The transformation of the basic type}

The first cell of the dwelling is a hut after which families erect some kind of fence marking their domain, the fragility of which is emblematic, the demarcation being a largely symbolic gesture. After completion of the first core, the addition of one or two rooms to the original construction begins, and, later, another floor may arise. The construction system is simple and includes a concrete slab as cover, whilst the structure of the second floor is initiated by pillars with steel rods protruding from the standing structure, so that additional floors can be added, according to the future needs of the family. The possibility of extending the original dwelling to the sides or above is a fundamental necessity, whose purpose is to house the family or an additional source of income. The final step of the construction process is to transform the previously constructed roof slab into the so-called "varanda paulista". It transforms the old terrace into a covered free space on the last floor of the building. This element is used as a domestic service area on weekdays and for social use and dances at neighbour and family gatherings at weekends. It also represents an enclosed area where the traditional socialising and collective street functions can now take place, the families turning to the private so as to escape the public street space appropriated by gangs and drug dealers.

\section{Late twentieth century segregated fabric}

The other urban fabric that stands out is a result of the metropolitan expansion. This occurred with greater intensity in the late twentieth century, integrating low-density, upper-class residential neighbourhoods, structured along extended blocks and located in neighbourhoods or condominiums adjoining the city domains. Such urban phenomena are not normally part of a cohesive urban whole and may be considered as fragments of a situation unrelated to the municipality in which they are located. The direct benefits to the municipality's population, such as jobs and taxes, are limited. The effect such fabric produces on the urban landscape is very similar to that of the favelas in their initial form, but with reduced density (Perna, 2012). 
The principle that guides the design of the urban plan refers to the figure of an axis which leads to the crest and is adapted to the relief by means of penetration routes that circumvent the slope. In this fabric, the street system takes the form of a series of parallel roads drawn in terraces, which form long blocks. Plots have regular proportions. If compared to the favelas, they would constitute the area of the glebe, perpendicular to the road system, which brings the need for cuts and landfills for the construction of housing units. In these places, large lawns are valued, with the residential units being pushed back from the boundaries, whilst the land cuts are contained by high walls to prevent landslides and erosion.

The residential unit is composed of a dwelling implanted at different levels, with intermediate floors, garages for several automobiles and leisure amenities: swimming pools and tennis courts in the gardens, all surrounded, with strict access control and restricted access to the domains. And yet, due to the planning ideology of exclusion and segregation, the use of strategies and mechanisms for urban security, as manifested in the segregation itself, is not perceived.

\section{Final considerations}

Belo Horizonte, as manifest in 2017 , is very different to the city envisaged in the original concept and plan, its evolution being the result of both public and private actions. It can be observed, as morphologists acknowledge, that the urban form is a product of historical eras subject to political, economic, and social pressures that influence therein the morphological periods. The facts reveal that in Brazilian cities, such as Belo Horizonte, there are formal and planned spaces with regular fabric containing single or multifamily dwellings, structured on defined plots and blocks with adequate infrastructure. At the same time, there are unregulated spaces, many of them located in high-risk areas that form dense urban fabric with small plots and poorly delineated blocks that fit the terrain forming continuous patches.
This work has then attempted to present and discuss the appearance of such phenomena and has demonstrated that planning has always been aimed at the economically better served sectors. On the other hand, when observing the urbanization, resulting from collective and spontaneous decision making, it is possible to observe that the urban plans are similar to those of the planned cities and that they sometimes bring interesting social qualities, unknown in those developments destined for the high income social classes.

Thus, it can then be observed that the urban fabric has been transformed and all forms present, at their core, the contradictions and social maladies that have fallen upon Brazilian society, in the form of urban violence. This has in turn required the great majority of inhabitants to use strategies and mechanisms to increase security, which has sadly and invariably led to the loss of the social use of the spaces on the streets and to the control and segregation of private space.

Finally, and more generally, it is hoped that this research can contribute to assessing the pertinence of applying morphological studies in situations which have been little explored. Thus, the identification and study of urban fabric, resulting from social and economic inequalities, could constitute a source of further fruitful investigation. It may also reveal that such research can be innovatively and productively applied in countries exhibiting similar phenomena and, consequently, further contribute to developments in the study of Urban Morphology.

\section{Acknowledgments}

Authors acknowledge the support received from Fundação de Amparo à Pesquisa de Minas Gerais -FAPEMIG, from Conselho Nacional de Desenvolvimento Tecnológico e Cientifico$\mathrm{CNPq}$ and Coordenação de Aperfeiçoamento de Pessoal de Nível Superior - CAPES for the development of this paper. 


\section{References}

Barreto, A. (1996) Belo Horizonte, Memória Histórica e Descritiva; História Antiga e História Média. (Fundação João Pinheiro, Centro de Estudos Históricos e Culturais, Belo Horizonte).

Bonduki, N. (1999) Origens da habitação social no Brasil: arquitetura moderna, lei de inquilinato e difusão da casa própria (Estação Liberdade/FAPESP, São Paulo).

Caniggia, G. and Maffei, G.L. (2001) Interpretating Basic Building: Architectural Composition and Building Typology (Alinea, Firenze).

Conzen, M.R.G; Conzen, M. P. (2004) Thinking about urban form: papers on urban morphology, 1932-1998 (Peter Lang, Oxford).

Ferreira, M. G. (1997) 'O sítio e a formação da paisagem urbana: um estudo do município de Belo Horizonte', unpublished Ms thesis, Universidade Federal de Minas Gerais, Belo Horizonte, Brazil.

Gimmler Netto, M. M. (2014) 'A paisagem de Ouro Preto', unpublished Ms thesis, Universidade Federal de Minas Gerais, Brazil.

IBGE, (Instituto Brasileiro de Geografia e Estatística) (2011) Censo 2010 (http://www. ibge.gov.br/cidadesat/topwindow.htm) accessed 21 November 2011.

Landscape Laboratory (2010) Teixeira, M. C. V; Maciel, M. C.; Pereira Costa, S. A. 'A transformação dos espaços livres públicos de Belo Horizonte', in Anais do $5^{\circ}$ Colóquio Nacional QUAPÁ-SEL (Universidade de São Paulo, São Paulo).

Libânio et al (1988) PROFAVELA: o morro já tem vez (Companhia Urbanizadora de Belo Horizonte- Urbel, Belo Horizonte).

Macedo, S. S. (1999) Quadro do Paisagismo no Brasil (QUAPÁ/ FAU/USP, São Paulo).

Maricato, E. (1999) Habitação e desenvolvimento urbano: o desafio da próxima década. (http://www.usp.br/ fau/depprojeto/labhab/biblioteca/textos/ maricato_habitacaodesafiodecada.pdf) accessed 12 may 20 .

Maricato, E. (2015) Para entender a crise urbana (Expressão Popular, São Paulo).

Pereira Costa, S. A. (2004) 'Transformações, conflitos, perdas e permanências na Paisagem Sul Metropolitana de Belo Horizonte', unpublished $\mathrm{PhD}$ thesis, Universidade de São Paulo, Brazil.

Pereira Costa et al (2010) 'The Public Architecture Programme and the 9 de Março squatter settlement in Barbacena, Brazil', Urban Design International 15- 2, 1105 -118.

Perna, S. A. (2012) 'Paisagem em transformação: o eixo da MG 030 em Nova Lima', unpublished thesis, Universidade Federal de Minas Gerais, Brazil.

PLAMBEL (1986) A Estrutura Urbana da Região Metropolitana de Belo Horizonte (Secretaria do Estado do Planejamento e Coordenação Geral, Belo Horizonte).

ROLNIK, R. (2015) Guerra dos lugares: a colonização da terra e da moradia na era das finanças (Ed. Boitempo, São Paulo).

SANTOS, M. (2008) O espaço dividido: os dois circuitos da economia urbana dos países subdesenvolvidos.. Editora da Universidade de São Paulo, São Paulo) .

Secretaria Municipal da Coordenação de Política Urbana e Ambiental (2002) Programa BH Verde: resultados preliminares (Prefeitura Municipal, Belo Horizonte). 